\title{
NAVIGATION CHANNEL WIDTH CALCULATIONS FOR MALAYSIA'S DRAWBRIDGE BASED ON THE PIANC METHOD
}

\author{
AMIRUL KAMIL MUNAWWAR AZHAR* AND NOOR APANDI OSNIN
}

Faculty of Maritime Studies, Universiti Malaysia Terengganu, 21030 Kuala Nerus, Terengganu, Malaysia

*Corresponding author: p3053@pps.umt.edu.my

http://doi.org/10.46754/jml.2021.08.002

\begin{abstract}
This study concerns the risks of navigation of the marine traffic channel for the first Malaysian iconic Terengganu Drawbridge in Duyong Island, Terengganu. According to the Permanent International Association of Navigation Congresses (PIANC) (2014), insufficient navigation widths can lead to increased risk of navigation. In maritime logistics, everything has an element of hazard and risk, thus safety is very important when working in the maritime industry. The objective of this study is to calculate the safest width of a navigation channel which could assist in mitigating the risks and help to prevent a major accident. The methodology used by this study to calculate the width of the navigation channel uses formulas advocated by the PIANC harbour approach channels design guidelines report no 121-2014. The results of the calculations will then be compared to the width of the existing channel. The factors that are included in this calculation formula include vessel designs that regularly navigate the area, wind, and current speeds, and tidal heights. Based on the study findings, the total width required for the safe navigation of the drawbridge channel calculated using the PIANC calculation method is 37 meters. The existing navigation channel is only 25 meters which is a difference of 12 meters. This study however found that the existing channel is still safe for marine navigation even with the smaller width. Due to other factors including the frequency
\end{abstract}

Keywords: Hazard, risk, navigation channel, draw bridge, safety

\section{Introduction}

Terengganu has a lot of rivers and one of the famous ones is Terengganu River. This river originats from Kenyir Lake. It flows through the state capital of Terengganu, Kuala Terengganu into the South China Sea. This river has been particularly important to the locals since a lot of maritime activities have been actively conducted there including, fishing activities, offshore crew transport service, shipyard services, and recreational water sports.

This area is close to the Duyong Island jetty. The area is also home to the MSET Ship building company shipyard which is involved in ship dry docking and repair as well as an offshore crew jetty. The Aims Global Maritime agency uses the jetty to transport offshore crew on boats.

Terengganu's maritime industry is well developed; with a miner boat and amphibian bus to the iconic drawbridge under review. This shows potential for great economic growth in the State.
Terengganu River is an inland waterway that is located near Duyong Island. This river lane has been a popular mode of transport for many years.

Before this, it was known as the place for boat builders and these days, it has morphed into one of the busiest waterways in the country. This is in part due to a high number of maritime activities conducted on or near the river such as ship building, offshore crew transport, yacht racing, fishing, and as a home for many government agencies.

This sheer volume of maritime activities will surely increase the volume of marine traffic flow and the capacity of the vessels that traffic the waterway. Which may lead to major hazards. It is said that "Collision in inland water transportation represents the biggest treat to inland water transportation; happens infrequently but has grave consequences that makes avoiding such mishaps imperative (Sulaiman et al., 2011). 
The Terengganu Drawbridge is an iconic structure that will link Kuala Terengganu city centre to Kuala Nerus via the Seberang Takir, crossing on the Terengganu River. The overall length of the bridge is $632 \mathrm{~m}$, with a width of 23 $\mathrm{m}$ and the main reason it was built is to reduce traffic congestion on Sultan Mahmud Bridge (Zelan-Berhad, 2018).

According to Madehow (2018), a drawbridge is a movable bridge that can be lowered or raised accordingly. Usually, a drawbridge is built over a navigational waterway. This kind of bridge moves to allow boats and ships to cross under the bridge. These types of bridges are more expensive to operate and maintain than stationary bridges.

They can also impede traffic on a waterway when they are lowered and, on the roadway, or rail line when they are raised. The construction of this drawbridge was fraught with risk both before and after the bridge was completed. According to Hashim (2017), after dredging works in 2006, the exiting navigational channel had the width of $100 \mathrm{~m}$ and the draught of $7 \mathrm{~m}$. However, when the drawbridge was built, the channel width reduced to $25 \mathrm{~m}$ because of the bridge pillars. The draught also decreased due to the sand trapped underneath the bridge. Vessels would be constrained by another factor which is limited air draft that is only $10 \mathrm{~m}$ in height.

The drawbridge's existence will not only increase the density of marine traffic, but it will also increase the number of hazards leading to high-risk conditions.

\section{Literature Review}

\section{Hazard}

Hazards have the potential to give out threaten human life, health, property or the environment (International Maritime Organization, 2002). potential damage, harm, or adverse health effects on something or someone (CCOHS, 2018).

Anything that has the potential to harm people, the environment, property, and marine stakeholders will be classed as a hazard. Errors made in assessing the consequences and frequency of incidents, which can be cancelled out over the full spectrum of incidents that result in an underestimation of the overall risk profile is called a hazard.

Based on the DNV (2001), marine hazards that may give risk to major accidents such as structural failure, collision, and capsize must be covered in the safety case, which must show that their risks have been made as low as reasonably practicable (ALARP). The other marine hazards such as loss of position keeping and loss of utility systems might be covered in the safety case as the possible initiators of major accidents, or in response to the more general duty. There are so many examples of hazards around us and just waiting for us to make mistake.

This paper focuses more on maritime hazards and risks faced by seafarers. The few examples of the hazards are listed in the table below.

\section{Types of Vessel}

This shows the types of vessels that frequently use the navigational channel at Terengganu River. Listed are also the IMO or vessel call sign, Gross Tonnage (GT), Length Overall (LOA), Breadth, and vessel Draught. Vessel Characteristics are very important since they can give the idea of what is the largest vessel that can safely make use of the channel.

\section{Environmental Conditions}

Weather conditions are a crucial part of navigating water-bound vessels. When it comes to risk, weather conditions play a vital role in ensuring safe passage of marine users. According to the Department Of Occupational Safety And Health Malaysia (DOSH), weather conditions are considered a hazard. And since nothing can be done to control Mother Nature so this hazard is classed as a force majeure event that cannot be mitigated. However, the safety and technology aspects need to be upgraded to reduce the risk ranking. 
Table 1: Vessel characteristics at Terengganu river

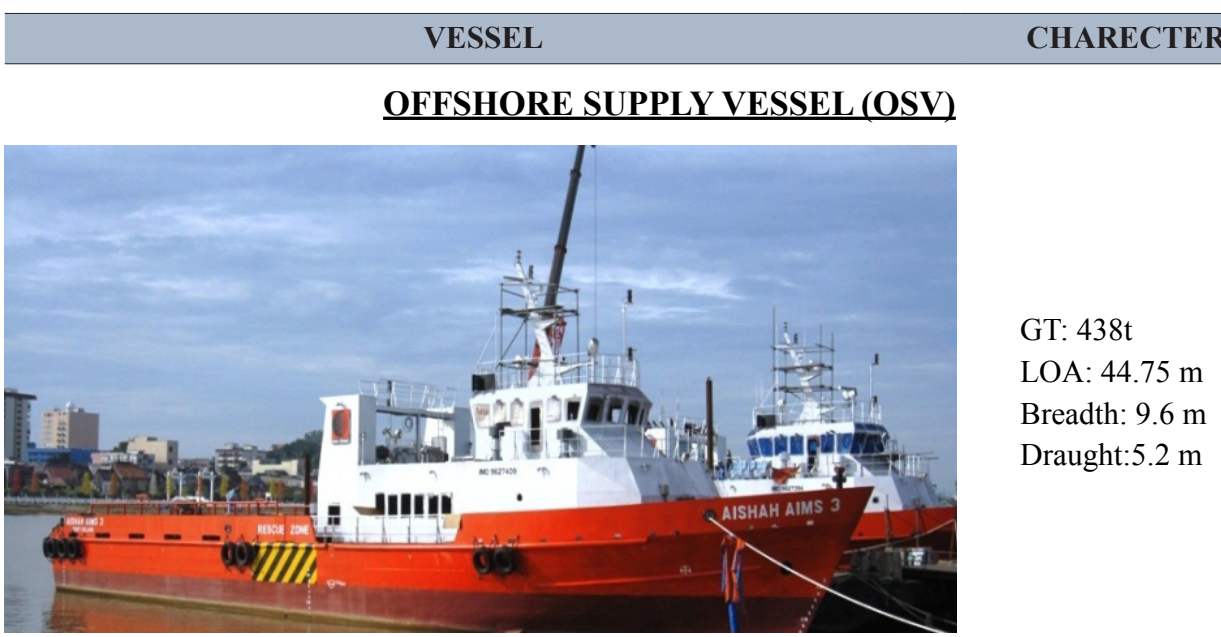

AISHAH AIMS 3

IMO: 9627409

\section{YACHT}

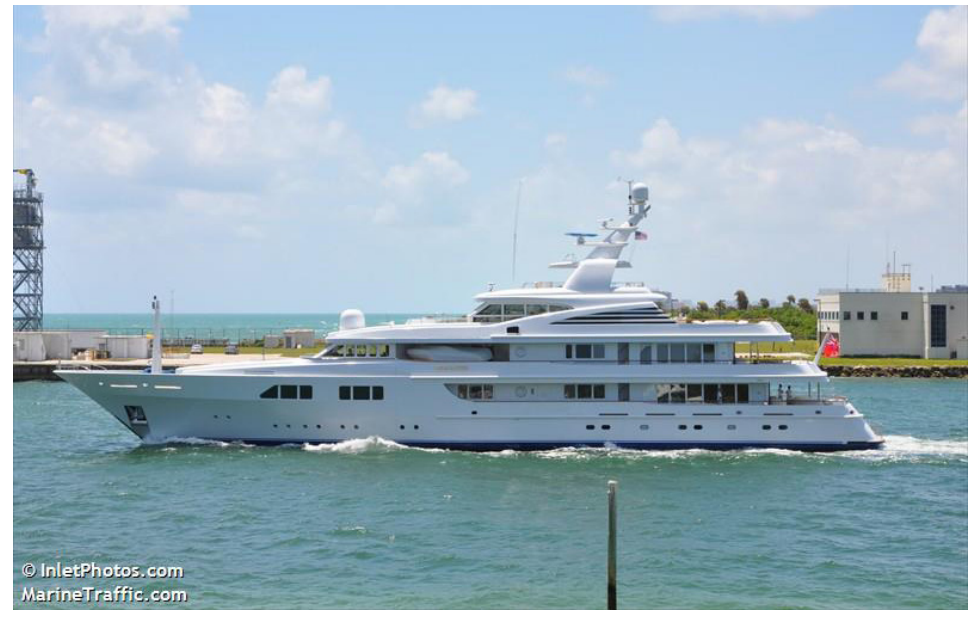

GT: $1092 \mathrm{t}$

LOA: $60 \mathrm{~m}$

Breadth: $10 \mathrm{~m}$

Draught: $6.3 \mathrm{~m}$

PARAFFIN

IMO: 1006946

Source: Marine Traffic (2019); Jabatan Perikanan Malaysia (2021) 

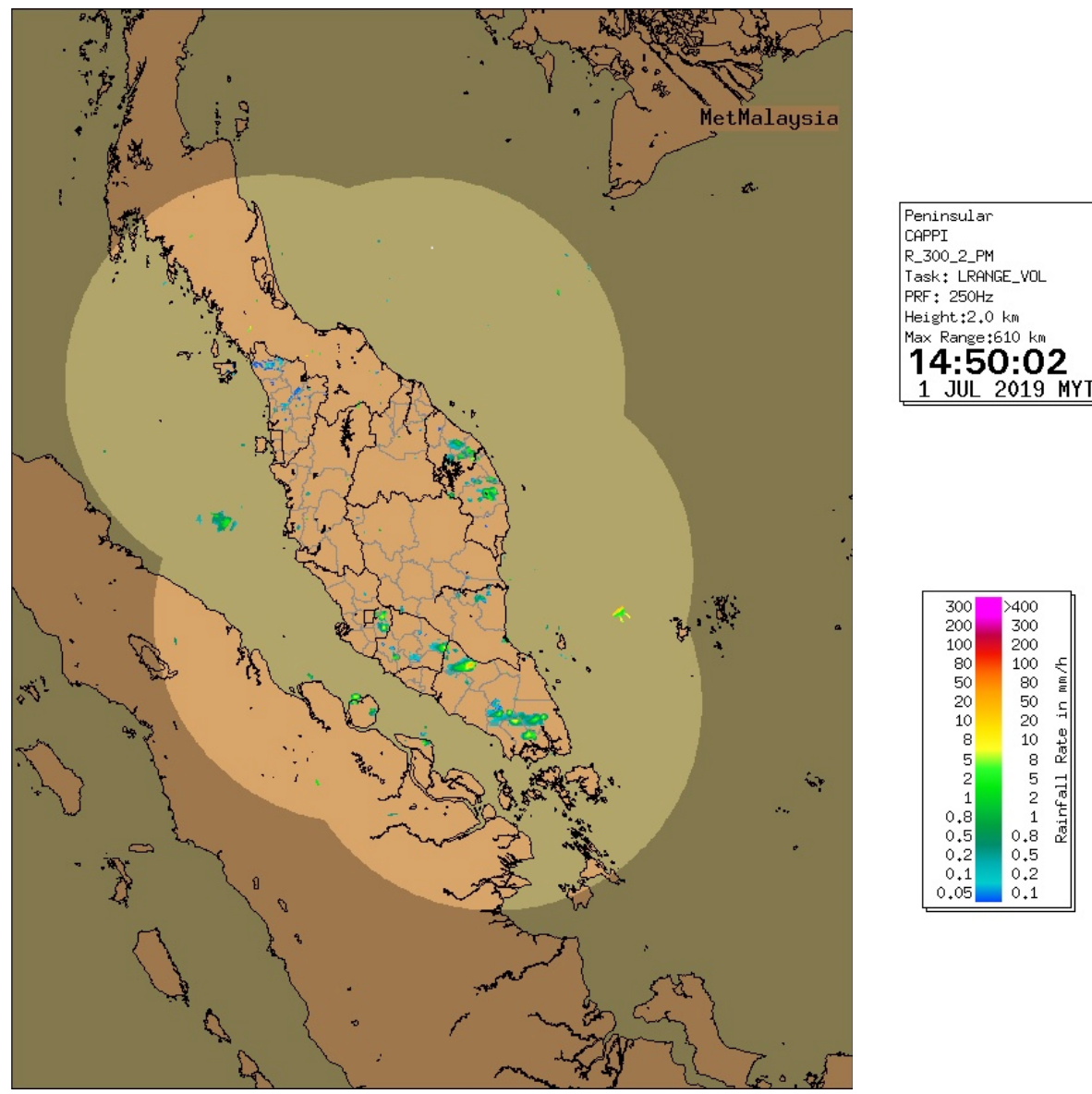

Figure 1: Rainfall distribution in Malaysia

Source: Meteorology Malaysia (2019)

Wind is defined as the horizontal movement of air across the surface of the earth and the direction from which it blows, and its speed is an important characteristic (Frampton, 2010).

Sanderson (1994) says, wind is simply the movement of air due to the differences in atmospheric pressure from one place to another. So, wind direction is not constant and will change depending on the atmospheric pressure.
Usually, wind speed is measured in knots. Wind speed will also affect the navigation of ships especially is areas with high winds. According to Malaysia Meteorology Department, the wind speed at Duyong Island, Kuala Terengganu ranges between 5 knots and 20 knots. The worst weather on record reached up to 30 knots. The direction of the winds is from South and Southeast. 


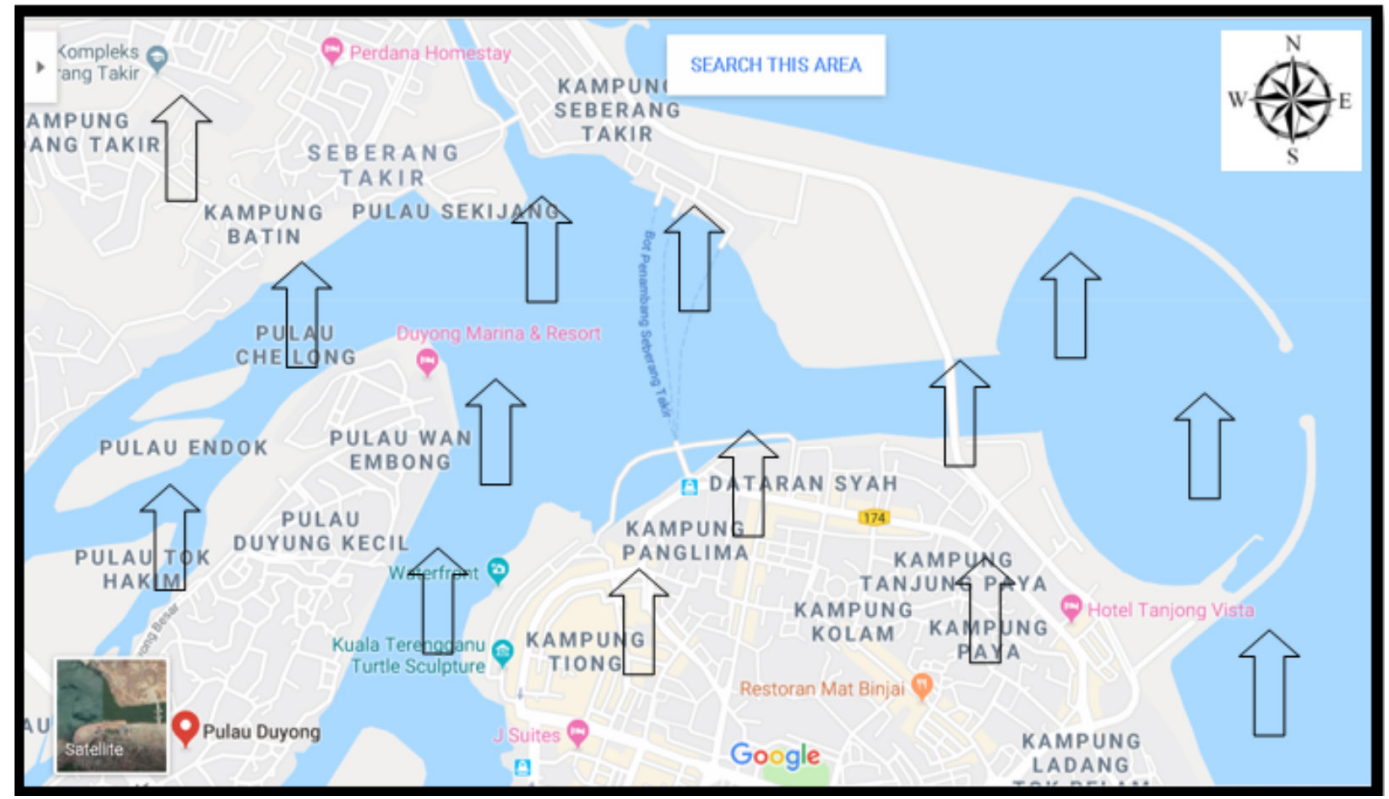

Figure 3: Direction of wind during ebbing

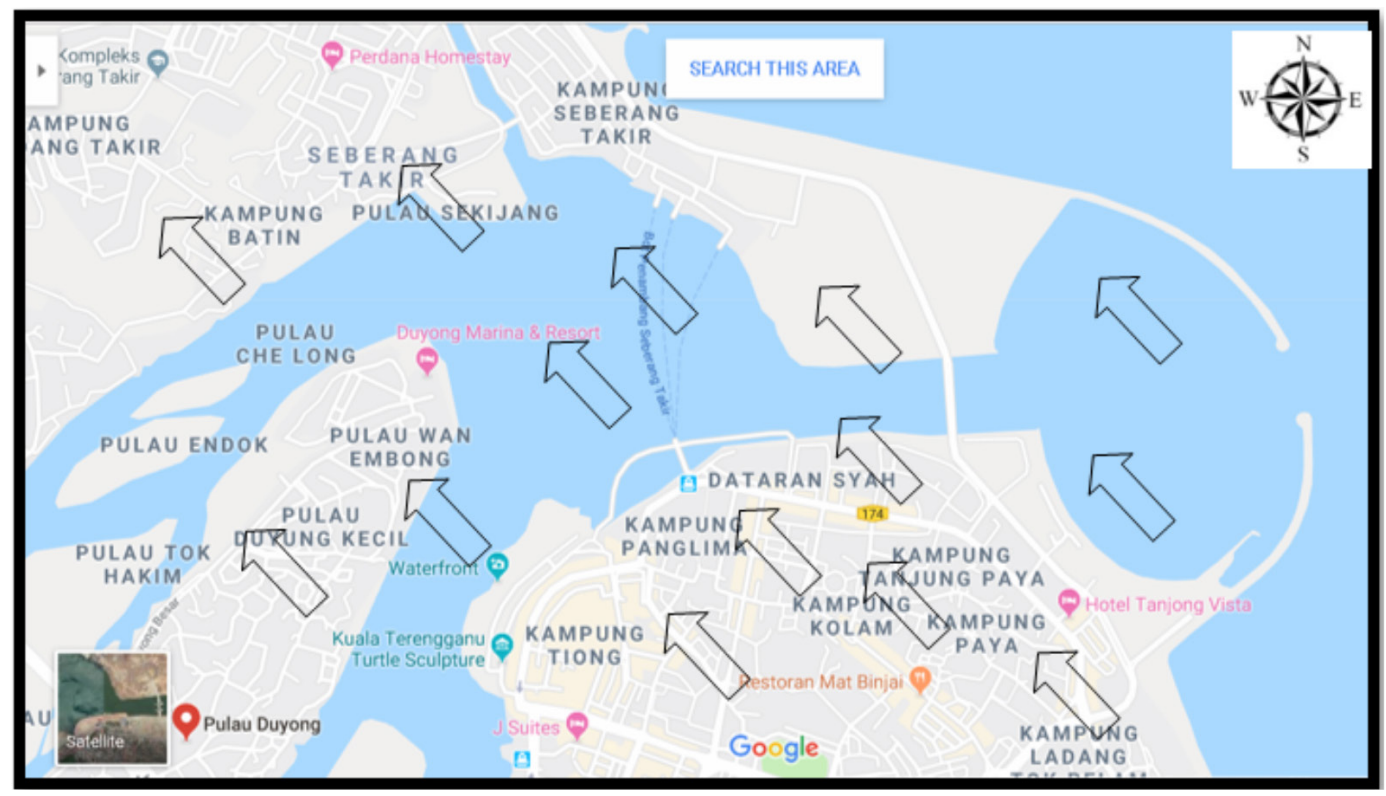

Figure 4: Direction of wind during flooding

Wind is defined as the horizontal movement of air across the surface of the earth and the direction from which it blows, and its speed is an important characteristic (Frampton, 2010).
According to Malaysia Meteorology Department (2019), the normal wave height at Duyong Island ranges between $0.5 \mathrm{~m}$ up and 1.5 $\mathrm{m}$. The worst case would be $2.0 \mathrm{~m}$ height and that is when the monsoon hits around July up to December. 
On a typical day, waves would be smooth with $0.2 \mathrm{kt}$ swells. According to National Geographic (2019), current is formed due to the movement of the seawater that acts by gravity, wind, and water density. The movement of the current is usually in horizontal and vertical direction. Current is another important element of ship navigation. The effect of the currents can be felt if the vessel has a high-water draught. Current flows in the area under review ranged between 0.5 and 2 knots (Malaysia Meteorology Department).

Table 2: Tidal table

\begin{tabular}{|c|c|c|c|c|c|c|}
\hline Place & Lat & Long & \multicolumn{4}{|c|}{ Height in meters above Datum } \\
\hline Kuala & $5^{\circ} 21^{\prime} \mathrm{N}$ & $103^{\circ} 08^{\prime} \mathrm{E}$ & MHHW & MLHW & MHLW & MLLW \\
\hline Terengganu & & & 2.5 & 1.9 & 1.0 & 0.4 \\
\hline
\end{tabular}

Source: Navigation Chart no: MAL 6522 Kuala Terengganu

\section{Methodology}

Most of the methods used in this study will be based PIANC Harbour Approach Channels Design Guidelines Report No 121-2014 (PIANC, 2014) which will strengthen the methodology of this study.

\section{Permanent International Association of Navigation Congresses (PIANC)}

The PIANC guidelines were consulted throughout the course of this study to validate the design of vertical and horizontal dimensions of the inner harbor approach channels, which include the maneuvering area. The guidelines were used to further support the defining restrictions for operations within the river navigational channel.

The methodology applied for validation of channel width was based on the PIANC guidelines using a process consisting of concept design, where empirically based methods were used. The horizontal dimensioning proposed under the channel concept design was reviewed using empirical method to ascertain that recommended channel widths were sufficient to ensure safe navigation allowing for various width factors associated with ship maneuverability, speed, prevailing wind, current and wave forces, aids to navigation, surface condition of channel bed, water depth and cargo hazard level. For this study, it will only focus on the PIANC report which includes channel width, harbour entrances, maneuvering, and anchorage areas. There is a calculation on how to determine the safest and sufficient width of the channel for the existing ship to maneuver.

According to PIANC (2014) concept design methods for straight channels state that this method is a modern practice in channel width design that should provide adequate navigational safety in the concept design phase. Although it can be applied to access channels worldwide, local conditions may require an optimization with respect to cost, operational conditions, and environmental aspects that may be carried out using the detailed design methods.

This study already knows the existing width channel and for the past few years, there have been no major accidents recorded in the area.

The equation:

For one-way channel:

$$
\mathrm{W}=\mathrm{W}_{\mathrm{BM}}+\mathrm{Wi}+\mathrm{W}_{\mathrm{BR}}+\mathrm{W}_{\mathrm{BG}}
$$

For two-way channel:

$$
\begin{aligned}
& \mathrm{W}=2 \mathrm{~W}_{\mathrm{BM}}+\mathrm{W}_{\mathrm{BR}}+\mathrm{Wp}+2 \mathrm{Wi} \\
& \mathrm{Where:}
\end{aligned}
$$


- $\mathrm{W}_{\mathrm{BM}}=$ width of basic maneuvering lane as a multiple of the design ship's beam B.

- $\mathrm{Wi}=$ additional widths to allow for the effects of wind, current etc.

- $\mathrm{W}_{\mathrm{BR}}, \mathrm{W}_{\mathrm{BG}}=$ bank clearance on the red and green sides of the channel

- $\mathrm{Wp}=$ passing distance, comprising the sum of a separation distance between both maneuvering lanes $\mathrm{W}_{\mathrm{M}}$ and an additional distance for traffic density.

The basic maneuvering lane widths $\mathrm{W}_{\mathrm{BM}}$ for ships with good, moderate, and poor ship maneuvering characteristics. Maneuverability of tankers and bulk carriers are generally poor, container vessels, car carriers, RORO vessels, LNG, and LPG vessels moderate while twinpropeller ships, ferries and cruise vessels are generally good.

The maneuvering lane WM consists of the basic maneuvering lane WBM plus additional widths Wi to account for environmental and other navigation effects on maneuvering. The environmental allowances as a function of ship speed and channel exposure to waves. In general, the use of this table in selecting channel width dimensions should be based on operational limit conditions if they are known. If it is unknown, then prevailing conditions can be used. For instance, with cross winds, it is unnecessary to dimension for a 33 knots wind if the operational limits restrict the use of the channel to winds of 30 knots or less.

To determine additional width for passing distance in two-way traffic, the beam of the largest passing vessel should be used whether it is the designed ship or not. The value given is the distance between the lanes of a two-way channel (not the hull-to-hull distance). Overtaking requires more width than passing but is normally not considered in concept design.

Heavy traffic is defined as more than 3 design vessels per day. In case of heavy (design) vessel traffic, an additional width of $0.5 \mathrm{~B}$ could be added.

\section{Results and Discussion}

\section{Basic Manoeuvring Lane WBM results}

The basic maneuvering lane widths $\mathrm{W}_{\mathrm{BM}}$ for ships will be good ship maneuvering characteristics. Maneuverability of the biggest ship recorded at study area is twin-propeller ships, ferries, and cruise vessels type which have generally good maneuverability. The vessel characteristics used for this study have an LOA of $60 \mathrm{~m}$, breadth of $10 \mathrm{~m}$ and draft of $6.3 \mathrm{~m}$. based on marine traffic (2019) the WBM is $1.3 \mathrm{~B}$.

\section{Environmental and Other Factors Wi}

The elements that need to be considered when navigating a vessel are the winds, currents and waves. Since weather conditions are crucial to mariners, as was said "strong winds and their constant companions, rough seas, probably present the most serious hazard faced by yachtsmen" (Sanderson, 1994). It is clear therefore that, weather conditions can be classified as one of the hazards that contribute to high-risk events especially at sea.

Wind is defined as the horizontal movement of air across the surface of the earth and the direction from which it blows, and its speed is an important characteristic. According to Frampton (2010), wind is simply the movement of air due to the differences in atmospheric pressure from one place to another. So, wind direction is not constant and will change depends on the atmospheric pressure. Wind speed will usually be measured in knots. The wind speed will also affect the ship navigation especially for those in high wind age area. According to Malaysia Meteorology Department (2019), the wind speed at Duyong Island, Kuala Terengganu is between 5 knots and 20 knots. The maximum it has reached during bad weather is 30 knots. The direction of the wind is from South and Southeast.

The normal wave height at Duyong Island ranges from between $0.5 \mathrm{~m}$ and $1.5 \mathrm{~m}$. The worst-case scenario when the monsoon hits around July to December has seen waves with 
a $2.0 \mathrm{~m}$. On a typical day, the waves would be smooth with $0.2 \mathrm{kt}$ swells.

According to National Geographic (2019), current is formed due to the movement of the seawater by gravity, wind, and water density. The movement of the current is usually in horizontal and vertical direction. Current yet another important element of ship navigation. The effects of the current can be felt if the vessel has high water draught. Currents in the area under review at the time of the study ranged between 0.5 and 2 knots. Based on the findings with relation to the value for $\mathrm{Wi}$ is $1.4 \mathrm{~B}$.

\section{Additional Width for Bank Clearance WBR and $W B G$}

Bank clearance is defined as slopping channel edges. A ship close to the edge of its manoeuvring lane will experience bank effects which are at a controllable minimum. Based on these, the findings show the edge slope is the bridge pillar since that will be the measurement for the navigation width and not the river slope. The type of slope will be steep and hard embankments, structures with low vessel speed approached so the result for WBG and WBR is $0.5 B$.

Total Results of Recommended Navigation Channel Width Based on PIANC Formula

For one-way channel (equation 1):

$$
\mathrm{W}=\mathrm{W}_{\mathrm{BM}}+\mathrm{Wi}+\mathrm{W}_{\mathrm{BR}}+\mathrm{W}_{\mathrm{BG}}
$$

Substitutes all the formula with determining results:

$$
\begin{aligned}
& \mathrm{W}=1.3 \mathrm{~B}+1.4 \mathrm{~B}+0.5 \mathrm{~B}+0.5 \mathrm{~B} \\
& \mathrm{~W}=3.7 \mathrm{~B} \\
& \mathrm{~W}=3.7 \times 10 \text { meters (vessel design breadth) } \\
& \mathrm{W}=37 \text { meters (recommended channel } \\
& \text { widths) }
\end{aligned}
$$

$B$ is the breadth of the vessel used for this study as per mention above is $10 \mathrm{~m}$ so the recommended width channel will be 3.7 times of vessel breadth, given the sum of 37 meters width for safe navigation of the channel based on PIANC guidelines. The existing navigation channel width is 25 meters and the difference between existing and calculated channel width is 12 meters.

\section{Conclusion}

As a conclusion, the existing navigation channel is insufficient for one-way channel according to PIANC guidelines calculation. The recommendation for the total width navigation channel of the first Malaysia iconic drawbridge Duyong Island Terengganu by PIANC is 37 meters.

While the existing channel width is 25 meters, the 12 meters difference does not mean that the existing channel is not safe for marine navigation. This is because a lot of other factors are needed to in order to make that determination such as the frequency of the biggest vessel coming into the channel, the number of accidents recorded, and human error factors. The limitations faced during the conduct of this study include the fact that it was completed without any grant or external financial support. This limited the resources that could be utilised for data c ements.

Official reports are not made. There are some incidents reports culled from newspaper reports, however, no official record was found. This study could be proven more by conducting a real-time simulation studies in future so the width channel and its safety could be verified and validated. The maritime industry is the largest and oldest sector of trade and exploration.

The safety of this marine waterway needs to be considered so that its value and utility will never fade. In conclusion, this study has proven that the width of the Terengganu Drawbridge channel in Duyong Island is insufficient according to PIANC guidelines, but it still safe for the river users to use at present. 


\section{Acknowledgements}

The authors would like to thank the Malaysian Maritime Enforcement Agency, Malaysian Marine Department, University Malaysia Terengganu, the experts, local community, and all those who had cooperated or assisted with this study.

\section{References}

Canadian Centre for Occupational Health and Safety [CCOHS]. (2018). The CCOHS Story: Forty Years of Service Annual Report 2018. Retrieved from https://www.ccohs.ca/ ccohs/reports/annual/2018/annual1819. html

DNV. (2001). DNV Rules for Classification of Ships. Retrieved from https://rules.dnvgl. com/servicedocuments/dnv/packages?ca tegory $=$ rulesship\&edition $=\% 20$ with $\% 20$ amendments\%202017-07

Frampton R. M, U. P. (2010). Meteorology for Seafarers. In U. P. Frampton R.M. Meteorology for Seafarers (pp. 39-48). Glasgow: Brown,Son \& Ferguson LTD.

Hashim, A. A. (2017). 'Drawbridge'; Musnahnya Legasi Warisan Pesisir Air Bahagian 2. Retrieved from buletinonline: https://buletinonline.net/v7/index.php/ drawbridge-musnahnya-legasi-warisanpesisir-air-bahagian-2/

International Maritime Organization. (2002). Guidelines for Formal Safety Assessment (FSA) for Use in the IMO Rule-Making Process. Albert Embankment, London, United Kingdom: International Maritime Organization.

Jabatan Perikanan Malaysia. (2021). Portal Rasmi Jabatan Perikanan Malaysia. Retrieved from https://www.dof.gov.my

Madehow. (2018). How Product are Made. Retrieved from madehow.com: http://www. madehow.com/Volume-6/Draw-Bridge.html

Malaysia Meteorology Department. (2019). Retrieved from met.gov.my: https://www. met.gov.my/forecast/marine/fishery/Co002
Marine Traffic. (2019, January 13). Retrieved from MarineTraffic.com: https://www. marinetraffic.com/en/ais/details/ports/22266

National Geographic. (2019). Ocean Currents. Retrieved from nationalgeographic.org:https:// www.nationalgeographic.org/topics/resourcelibrary-ocean-currents/?q=\&page $=1 \&$ per page $=25$

Permanent International Association of Navigation Congresses, International Association of Ports, Harbors, Joint PIANCIAPH Working Group II-, International Association of Lighthouse Authorities, \& International Maritime Pilots Association (1997). Approach channels: A guide for design (Vol. 2). PIANC.

Sanderson, R. (1994). Meteorology at Sea. (p. 71). Great Britain: Stanford Maritime.

Sulaiman, O. O., Saharuddin, A. H., Kader, A. S. A., \& Laily, A. R. N. (2011). Safety and Environmental Risk and Reliability Model for Inland Waterway Collision Accident Frequency. International Journal of Energy and Environmet, 4(3), 461-477.

Zelan-Berhad. (2018). Infrastructure ConstructionDrawn Bridge. Retrieved from Zelan Berhad: http://www.zelan.com/our-business/ engineering-construction/infrastructureconstruction/drawbridge/ 